\title{
Entrepreneurship in through Islam Perspective
}

\section{Vebby Anwar ${ }^{1}$, Sofyan Hamid ${ }^{2}$, La Ode Hidayat ${ }^{3}$ and Andi Harmoko Arifin ${ }^{4}$}

\author{
${ }^{1}$ STIE Pelita Buana Makassar, Indonesia \\ ${ }^{2}$ STIE AMKOP, Indonesia \\ ${ }^{3}$ STIKES Mega Resky, Indonesia \\ ${ }^{4}$ STIE Pelita Buana Makassar, Indonesia
}

\begin{abstract}
Entrepreneur is a strategic economic change agent for the Indonesian people in reducing poverty. By seeing that most of the Indonesia's population is Muslim, so it is very appropriate to implement an Islamic-based entrepreneurship system. Entrepreneur is a system in accordance with the teachings of Islam because it is highly recommended to seek risky or income. Islamic teachings view that work is worship, so that entrepreneurs besides can lift income per capita, also can reduce poverty. In this library research emphasize the importance of entrepreneur applied in Islam because in view of Islam is aspect of life which is grouped into human relations in social interactions according to the source of life problem which closely related to relation between human with God which will be accounted later in achiral. Business in the Qur'an is a human trade with God associated with spending his rescue to someone who cannot afford. Successful behavior in Islam cannot simply come; there are many values that need to be interpreted by Muslims as an entrepreneur. One of them, orientation which is a conception of a good self or someone else who becomes a habit as a way of life (way of life).Analysis of the success of an Islamic entrepreneur is to consider the variables of success and failure with internal and external factors based on Islamic teachings.
\end{abstract}

Keywords: Entrepreneur, Poverty, Islamic Perspective

\section{Introduction}

One that affects the growth and economic development of a nation can be seen from the growth of entrepreneurship in each country. Governor of Bank Indonesia stated that the number of entrepreneurs in Indonesia ideally 2 percent of the population so that economic growth can go faster. Entrepreneurs are strategic agents of economic change so that Indonesia can change from middle to lower middle country to upper middle-income country. The entrepreneurial group is known as human capital which has a role in advancing the economy. The progress of the Japanese and Chinese for example is driven by entrepreneurship. Based on statistical data of 2014 the number of entrepreneurs in Indonesia is still below 2 percent or about 1.65 percent of the population, far behind when compared to the number of entrepreneurs in other countries, such as in Malaysia, Singapore and Thailand which is already above 4 percent. Countries belonging to the lower-middle category tend to be more dominated by entrepreneurs in various forms, popularly known as Small Medium Enterprises (SMEs). SMEs in Indonesia are familiar with the terms Small and Medium Enterprises (SMEs).

Based on data http://bps.go.id prerelease 2018 explained that in September 2017, the number of poor people (population with per capita expenditure per month under the Poverty Line) in Indonesia reached 26.58 million people (10.12 percent), decreased by 1.19 million people compared to March 2017 condition which amounted to 27.77 million people (10.64 percent). The percentage of poor people in urban areas in March 2017 of 7.72 percent decreased to 7.26 percent in September 2017. While the percentage of poor people in rural areas in March 2017 of 13.93 percent decreased to 13.47 percent in September 2017. During the period of March 2017-September 2017, the number of poor people in urban areas fell by 401.28 thousand people (from 10.67 million people in March 2017 to 10.27 million people in September 2017), while in rural areas fell by 786.95 thousand people (from 17.10 million people in March 2017 to 16.31 million people in September 2017). 
On the other hand, the total labor force in February 2018 was 133.94 million people, up 2.39 million compared to February 2017. Accordingly, the Labor Force Participation Rate (TPAK) was 69.2 percent, up 0.18 percent. In more detail, of the total workforce, the actual working population is only 127 million people, or an increase of 2.53 million compared to February 2017. While employment has increased the percentage of the population working primarily on providing accommodation and eating drinking by 0.68 percent, other services 0.4 percent, and manufacturing industry 0.39 percent. "Meanwhile, the decreasing employment is agriculture 1.41 percent, construction 0.2 percent and education services 0.16 percent.

According to the Minister of Cooperatives and Small and Medium Enterprises (UKM) of Indonesia said, the number of new entrepreneurs Indonesia reached 3.1 percent of the population. This ratio is still lower than other countries such as Malaysia 5 percent, China 10 percent, Singapore 7 percent, Japan 11 percent and US 12 percent, this is delivered in the framework of the national entrepreneurial movement. Recognized or not, businesspeople are really needed. They open jobs, not looking for work. This is considered to bring benefits to the community. Especially in a competitive era like this. One must be able to create something new creatively. Therefore, being an entrepreneur is one effective instrument to reduce poverty and the lagging of a nation.

The word entrepreneurship or entrepreneurship does not exist in the sacred texts of Islam. However, it does not mean that entrepreneurship is not allowed in Islam. Quite the opposite, entrepreneurship is highly recommended. If judging carefully, Islam was originally a religion of merchants. Islam was born in a trading city and was spread by merchants. Until the 13th century, the spread of Islam was carried out by Muslim traders to various parts of the world. No wonder if entrepreneurship is already inherent and inherent with Muslims. Entrepreneurship gets a very high place in Islam. Islam elevates the merchants, giving it the honor of being the first profession required to pay zakat. Moreover, as a congregation appointed as a caliph, it is appropriate that we show leadership in the world.

In fact, Prophet Muhammad SAW constantly appealed to his people to run entrepreneurship in order to seek success. A hadith mentions that 9 out of 10 doors of fortune come from trading. In the letter of al-Jema'ah verse 10 is also affirmed, "When the prayer has been fulfilled, then you are scattered on the earth and seek the gifts of God and remember Allah as much as possible for you to prosper." In the letter there are two key words: look for it. That is, we are not only required to work and strive. But it also uses all the potential and business capabilities. An entrepreneur has the dream of raising a business, even if it starts from a small business. And to be great, he must dare to become an innovator and developer (developer) to maximize business opportunities and accept the risk of failure. The distinguishing feature of an entrepreneur is the creator of opportunity, innovator, and risk taker. Entrepreneur is not just limited to business world only. But there are several kinds of entrepreneur are: Business Entrepreneur, Government Entrepreneur, Academic Entrepreneur. Social Entrepreneurs, Technology Entrepreneurs and others. Therefore, as a Muslim, we must be able to develop the framework of Islamic value-based business in various fields of entrepreneur.

The word "entrepreneur" comes from English. In a Webster dictionary review, an entrepreneur is "someone who organizes, manages, and takes into account the risks of a business". Means the word entrepreneur or entrepreneurship is always associated with economic and business activities. According to McClelland (1961) "In order for a country or region to prosper should have at least 2\% of the entrepreneur's population".

Entrepreneur Paradigm. Paradigm is a collection of values that form a person's mindset as a starting point of his view. To change the paradigm, then recognize the paradigm first. Literally, the paradigm is a vision of reality to bring about better conditions in achievement. For that purpose, vision requires a system of values, norms and beliefs as the foundation. The paradigm of entrepreneur in a person can be seen from the effort he wants to do. For example, one desperately wants to open a business based on logic and common sense has a bright prospect, but the mind (paradigm) refuses to support itself. Various reasons in mind remain unsure and continue to assume negative (pessimistic) towards 
his efforts. Without realizing it has formed a less good paradigm through subconscious mind. Again, someone was surprised and disappointed to get a failure in the effort.

Paradigm or vision is the ideals of the future in the form of better conditions. For that, the next step is to recognize and observe the attitude of an entrepreneur. The explanation of entrepreneurial attitude has been conveyed by Santos (2010) through "Seven characteristics (nature) of an entrepreneur" namely: first, High Achiever or high dedication, commitment, ambitious and love. Second, risk takers or people dare to take risks in this life. All entrepreneurs are at risk that may fail or succeed. Third, Opportunity analyzers or people who always succeed in analyzing each opportunity. He was able to see whether there was something worthwhile when applied. Fourth, problem solvers or people who always try to solve problems not the other way around. That is. looking for trouble. Fifth, emotional ties or ties between businesses. Entrepreneurs have the will, work hard, trust, and never give up. Sixth, Confidence. Self-beliefs and assumptions. Seventh, High Level energy, which has extraordinary spirit.

According to A. Poverty (in Journal of P \& PT No. 9 of 1999) distinguishes entrepreneurship theory in two big groups, theoretical theory which prioritizes business opportunity (which is generally embraced by economists) and the theory that prioritizes people's response to the opportunity embraced by sociologists and psychologists). In the classification are economic theory, sociology theory, psychology theory, and behavioral theory.

In Economic theory, explains that when entrepreneurship we understand that prioritizes business opportunities, then developing entrepreneurship can be tangible actions that are (a) deliberately creating economic opportunities (b) disseminating information about economic opportunities (c) offering incentives for people willing to bear the risk become innovators and build organizations. In Sociology theory, Hagen proposed a theory based on the observation and analysis of historical developments in several countries. It is his conclusion that in all societies there are social groups that "give birth" to more entrepreneurs than with other groups. Hagen then reconfirms in the group those who are driven to become entrepreneurs are those whom the elite despise in society. In Psychology theory, according to M.C. Cleland that there is a relationship between entrepreneurial behavior and the need for achievement (nch). According to him nch is formed in childhood and is determined by the content of reading for elementary school. This means that it must be instilled early on. But then McClelland expanded his theory and concluded that achievement motives (achievement motivation) could be improved through training in adults. Therefore, together with winters and Berlet developed the Achievement Motivation Training (AMT) package; a business designed to improve business. Whereas as in behavior theory, according to Dracker entrepreneurship is behavior that is not seen as a personality trait He suggests three behaviors to support one's entrepreneurship (a) innovation (b) entrepreneurial management (c) entrepreneurial strategy.

The basis of entrepreneurial knowledge is innovation, meaning a new way of using resources to create wealth. To generate innovation, we must increase the sensitivity and ability of diagnostic or analytical skills. In Entrepreneurial English is an entrepreneur, the term was first introduced by Richard Cantillon, a French economist. According to him, entrepreneurs are "agent who buys means of production at certain prices in order to combine them". In the not-too-distant future, another French economist Jean Baptiste say added definition to the concept of entrepreneur as leader. In general, many definitions put forward by experts, about entrepreneurship, below I will point out some of these opinions, taken from various sources: Harvey Leibenstein $(1968,1979)$, argued, entrepreneurship includes the activities needed to create or execute the company when all markets have not yet been established or have not been clearly identified, or the component of the production function is not fully known. Penrose (1963): Entrepreneurial activities include identifying opportunities in the economic system. Managerial capacity or capacity differs from entrepreneurial capacity. Frank Knight (1921): Entrepreneurs try to predict and respond to market changes. This definition emphasizes the role of entrepreneurs in the face of uncertainty in the dynamics of the market. An employee is required to perform basic managerial functions such as direction and supervision. 
A sociologist named David McClelland argues that, if a country wants to prosper, at least $2 \%$ of the total population of the country's population becomes entrepreneurs, Indonesia itself to date according to a research the number of new entrepreneurs is about $0.18 \%$ the information that I read on the internet today on March 5, 2012, the number has soared to become so not surprising if at present, Indonesia's economic condition lags far behind neighboring countries that is Singapore which has 7\% of entrepreneur percentage, Malaysia 5\%, China 10\% especially if it must be compared with the United States superpower that almost $13 \%$ of the population become entrepreneurs.

Therefore, with the development of knowledge about entrepreneurship, it will encourage the Indonesian people especially the young generation or students, to join the job creation with entrepreneurship, not only become job seekers. Given the spirit of nationalism that the Indonesian nation must be able to compete in the world economic arena, it will be many students who are motivated to improve their quality and sparked creative ideas in the field of entrepreneurship that is highly competitive. Why with more and more entrepreneurs in a country will increase the competitiveness of the country, a country that has many entrepreneurs will certainly earn a substantial income from the tax sector, for their economic activity, just imagine if a country has too many or fewer civil servants even unproductive, then they take the state budget every month to pay them, but their contribution to the national economy is minimal both in terms of tax and consumption levels.

The more people become entrepreneurs, their economies will be independent, will not depend on the capitalist economic system, in this case the government must pro-actively provide capital for entrepreneurs to be truly productive with competitive interest, and not destroy the businessmen and the government, the results their business profits will be stored in the domestic banks, so that the money turns more smoothly, with their capital will increase so as to penetrate the global market share, which will increase the export-import balance and will increase the country's foreign exchange significantly, it is very clear that entrepreneurship has a very important role to raise the dignity of a nation in the international arena.

In terms of GNP (Gross National Product), if more money generated by the sons and daughters of Indonesia, because entrepreneurship then the money generated a greater chance, in contrast to the nominal salary is relatively fixed. GNP will increase the overall goods and services produced citizens of the population wherever located (at home and abroad), by increasing this GNP will further strengthen the national economy in macro, and accelerate the wheel of national development, because the availability of budget is increasing. From some positive effects of entrepreneurship, it can be concluded that entrepreneurship aims to improve the economy of society and generally improve the dignity and personal dignity of entrepreneurs and nation and state, with the knowledge is expected to more and more Indonesian citizens especially students who jump in the business, but need to be considered in trying to put forward honesty, so that what is produced can helpful for the wider community.

Entrepreneur of Islam. In the view of Islam, a Muslim or a Muslim is strongly recommended to make efforts to seek income or income. In a verse of the Qur'an in the letter of Al-Jumah, verse 10, it says "When the prayer has been done, then you are scattered on the earth, seek the gifts of God and remember Allah a great deal for you to be lucky" .7 From translation verses of the Qur'an, clearly indicate that God commands the human race to make an effort or to make a genuine effort by calling on humans to "scatter" on earth in search of the grace of God that has bestowed him on this earth.

According to Tasmara, more seriously, working for a Muslim is a "worship", a proof of his devotion and gratitude to cultivate and fulfill the divine call in order to be the best because they are aware that the earth is created as a test for those who have the best ethos ", We have created what is on earth as an ornament for him, that We may test them who is the best of his works "(Al-Kahf: 7). This verse has tapped the heart of every Muslim person to actualize work ethic in the form of doing everything with high quality. They realize that God tests himself to be a man of the finest deeds or deeds, and even they are aware that the requirement to encounter God is by doing prestigious deeds, as he says, 
"Whoever expects an encounter with his Lord, he does good deeds and let him not associate his Lord in worship with anything "(al-Kahn: 110).

There are many Islamic figures that we can emulate. In addition to Prophet Muhammad SAW, most of the Companions of the Prophet were also merchants. Abdurrahman Bin Auf for example. Abdurrahman Bin Auf is a friend of Prophet Muhammad SAW who is popular with his independence in entrepreneurship. When migrated to Medina, Abdurrahman Bin Auf was introduced to Sa'ad Bin Rabi 'Al Anshori, one of the most generous millionaires in Medina. At that time, Abdurrahman had been offered Sa'ad to choose one of his two vast gardens. But Abdurrahman refused. He simply asked Sa'ad to show the market location in Medina. Abdurrahman is a wealthy businessman who is very generous. He sympathized the veterans of War Badar and sympathized the widows of the Prophet. He also feeds the orphans and the poor in Medina. Abdurrahman Bin Auf is one of the best friends who have a great personality. He knows and is capable of how to place him. He can share tasks, either in the mosque, in the market, in the family, or on the battlefield. During the battle, he gave his business to the men. After the war, he will actively re-run the business.

$\mathrm{He}$ is a figure of exemplary. He is a successful and highly respected businessman. He not only has business acumen that shows his professionalism. But also, morality is a mirror of the personality of a leader. He has a great capacity and role in developing the socio-economic of Islamic society, especially in the city of Medina. From the beginning, there have been many sacrifices and suffering that he passed. Therefore, now he became one of the people whose name is recorded in Islamic history with gold ink. Now there is nothing more to worry about if you want to become an entrepreneur. The most important is how we incorporate the element of Islamic spirit into entrepreneurship. Islam emphasizes the importance of building and enforcing the culture of entrepreneurship in the life of every Muslim. This culture includes the basic traits that encourage being a creative person, reliable, and beneficial to the surrounding community. Mental is what will make us still exist in business battle. Unlike other public entrepreneurs, Muslims as business actors have very interesting characteristics. Successful Islamic entrepreneurs use different methods, or work systems with other people in general. The determinants of the success of Islamic entrepreneurs can be seen from the high dedication to what it does. Dedication can be a commitment, a love, or an ambition to align its business with the value of Islam. There is a determination or willingness to realize a business or business in a lawful way. Work hard; believe in the Qur'an and Hadith as the foundation.

Successful behavior in Islam cannot just come; there are many values that need to be interpreted by Muslims as an entrepreneur. One of them, orientation which is a conception of a good self or someone else who becomes a habit as a way of life. Analysis of the success of an Islamic entrepreneur is to consider the variables of success and failure with internal and external factors based on Islamic teachings.

The paradigm of Islamic entrepreneur can be applied through some obligatory or obligatory circumcision. Some of these are efforts to strengthen themselves to become true Islamic entrepreneurs. First, fasting benefits the mental and emotional health of entrepreneurs. When hungry, the body releases some chemicals to protect the brain, thus increasing one's mood to form a paradigm in building businesses and businesses. Second, Prayer. Typical prayers Dhuha not only nourish the body, also proved to have become a mental shield and improve the relationship of fellow Muslims to strengthen the relationship (relation) business. Third, read the Qur'an. Reading the Qur'an in the morning not only limited to making the mind calm and peaceful heart. Allah SWT says in Surah Yunus, verse 57: "O mankind, has come unto you a book of lessons from Your God and as a healing agent of the soul, for guidance and grace for those who believe."(Surah Yunus, 57)

Much science (research) shows that reading al-Qur'an after dawn can increase brain intelligence. Due to the time it takes a dark turn to light and vice versa. Lastly, praise God. The virtue of praise God is to cleanse the heart and maintain a peaceful, peaceful, and controllable psychiatric mood in running a business. Finally, the paradigm is a vision that requires a system of values, norms and beliefs in running a business based on Al Quran and Hadith to always achieve self-victory in the world and the 
hereafter. Hopefully. In the view of Islam, work and endeavor, including entrepreneurship, may be said to be an integral part of human life because of its existence as Khalifah Fil-Ardh intended to prosper the earth and bring it to a better direction. In Islam, the suggestion of trying and working as a realization of the human caliphate is reflected in the letter of Ar-Ra'd: 11. "To man there are angels who always follow him in turns, in front and behind him, they guard him by Allah's command. Allah does not change the state of a people so that they change the circumstances that are in themselves, and if Allah wills evil for a people, then no one can reject it, and there is no protector for them other than Him. (Surah Ar-Ra'd: 11)

As a religion that strongly emphasizes the importance of the empowerment of its people, Islam sees that trying or entrepreneurship is an integral part of Islamic teachings. There are several verses and traditions of the Prophet Muhammad (SAW) which explain the importance of the business activity. Among them: "When the prayer has been fulfilled, spread it out in the earth, and seek the gift of God" (Surah Al Jumuah: 10)

"If one of you takes a few ropes, then goes to the mountain and then returns to carry a bunch of firewood and sells it, then with that result God is sufficient for your life, it is better than begging fellow human beings, whether they give or no." (Bukhari).

Once the Prophet was asked by the Companions, "What is the best work done by the Prophet Muhammad? The Prophet answered, a person works with his own hands and every clean sale and purchase. (HR Al Bazar). Honest and honest traders are together the Prophet, the Shadiqin people, and the martyrs (HR Tirmizhi and Ibn Majah). Pay close attention to you, in fact the trade in this world is nine out of ten doors of sustenance (HR Ahmad). The above hadith shows how entrepreneurship is an inherent activity in the teachings of Islam. Such a strategic position of entrepreneurship and commerce in Islam, to Islamic theology can be referred to as "the theology of commerce" (commercial theology). It can be seen in the fact that the reciprocal relationship between God and man is a true trade, God is the perfect merchant. He (God) put the entire universe in His books. Everything is considered; each item is measured. He has made a book of accounts, balances, and $\mathrm{He}(\mathrm{God})$ has set an example for honest businesses.

\section{Research Methodology}

Type of research conducted is the type of research library research where obtained information from previous research. In the study Library study is a technique of collecting data by conducting a study of books, literature, records, and reports relating to problems solved. "(Nazr 1988: 111). Furthermore, according to Nazr (1998: 112) literature study is an important step where after a researcher set the topic of research, the next step is to conduct studies related to the theory related to the topic of research. In theory search, the researcher will collect as much information from the related literature. Literary sources can be obtained from: books, journals, magazines, research results (thesis and dissertation), and other appropriate sources (internet, newspapers etc.). Therefore, the literature study includes general processes such as systematic identification of theory, literature discovery, and document analysis containing information relating to the research topic.

\section{Result and Discussion}

Build Muslim Entrepreneurship. The effort to grow or build Muslim Entrepreneurship lately is no longer a necessary thing to do, but it is a must or must for every Muslim, especially Muslims in Indonesia. The obligation is caused by the urgent need for all Indonesian citizens to get out of the nation's economic weakness that causes decline in various economic sectors of the nation of Indonesia so that the economy becomes stagnant which if left will worsen the state of the country. From some opinions on the definition of entrepreneurship or entrepreneurship above, it can be concluded that entrepreneurship is a vigorous ability and courage to create a new business or expand an existing business optimally to gain greater benefits. So, entrepreneurship or entrepreneurship in this very closely related to the condition of a person's psyche or personality. Regarding the psychological value, 
every Muslim person should adorn it with positive and innovative habits and there is a strong willingness to show his personality as a Muslim in the form of performance outcomes and attitudes and behaviors that lead or lead to more optimal results.

The development of entrepreneurship among Indonesian people has benefits directly related to community development. These benefits include:

1. Entrepreneurship development will contribute greatly to the expansion of employment, thus reducing unemployment.

2. The development of entrepreneurship will increase the economic strength of the country. It has been proven in the history of our nation's journey that SMEs are the economic base most resistant to the multidimensional crisis.

3. As more and more entrepreneurs, including Muslim entrepreneurs will be increasingly prominent in society, especially in trading activities. Therefore, entrepreneurs have a superior person, brave, independent; life does not harm others, on the contrary to provide benefits for other members of society. Fourth, with the development of entrepreneurship, it will foster the work ethic and life dynamic, as well as the increasing participation of people on nation building.

The success of an entrepreneur in Islam is independent, meaning his superiority centers on his personal integrity, not from outside himself. This in addition to causing reliability to face challenges is also a guarantee not trapped in negative practices and contrary to the rules, both state regulations and religious regulations. Here is some of the integrity of these Muslim entrepreneurs visible in their properties. A Muslim entrepreneur has a firm belief in the truth of his religion as a way of salvation, and that with his religion he will be superior. This belief makes him do business and work as a praise God and rebuild and grateful post-business. Horizontally seen in his drive to develop his potential and his desire to always seek as much benefit as possible for others. While vertically intended to devote them to Allah SWT. Motivation here serves as a driver, determinant of direction and priority scale setting.

The Importance of Entrepreneurship in Islam. The notion that entrepreneurship and economic growth are closely related significantly has undoubtedly been successful from the start of research conducted by Schumpeter (Aghion and Howitt's, 1998). Entrepreneurship and trade in the view of Islam are aspects of life that are grouped into human relations in social interactions according to the source of life issues. The problem is closely related to relationships that are horizontal, the relationship between humans who will be accounted later in the hereafter. Man is commanded to prosper the earth and bring it to a better direction and commanded to seek fortune. In search of fortune then must look for wide open door and amount which many shares by Allah SWT. The door of many fortunes and wide open is through entrepreneurship. The entrepreneurial spirit is in the QS. Hud verse 61, QS. Al-Mulk verse 15, and QS. Al-Jumah verse 10.8 So in the Qur'an does not distinguish between entrepreneurship and religion. On the contrary, the Qur'an strongly supports the improvement of quality in entrepreneurship.

Entrepreneurship in Islam is a worship that will be rewarded if implemented and one of the international seminar writers (Nur Suhaili Ramli, Auckland, New Zealand in Islamic Entrepreneurship) says entrepreneurship is Fardhu Kifayah. The skills of everyone must be developed but not everyone should have the same skills. Islam does not provide explicit explanations regarding the concept of entrepreneurship (entrepreneurship), but between the two have a close relationship, has a spirit or soul that is very close, although the technical language used is different. In Islam is used the term hard work, independence (biyadihi) and not easily give up, at least there are some verses of the Qur'an or hadith that can be a reference message about the spirit of hard work and independence, such as: "the best charity is the work done with sweat Ahmed Dawood.) In a verse of Allah SWT says, "Work ye, and Allah and those who believe will see your work. (Sura-Tawbah: 105). Therefore, when the prayer has been fulfilled then you are scattered on the earth and seek God's gifts (risky). (Al-Jumu'ah : 10). 
Business in the Qur'an is explained that the activity of exchanging a valuable item with a currency through prescribed methods which include two meanings, namely: first, commerce in general which includes commerce between man and God. When one chooses the direction of God, loves Allah and His Messenger, fights in his way with wealth and soul, reads the book of God, establishes prayer, spend some of its sustenance, then it is the best trade between man and God. In one verse of the Qur'an it is explained that when a person purchases Allah's guidance with error, it includes a disadvantaged person.

Business begins with a small and personal trading, by buying goods from one market and selling to others. Other business activities with a number of people in the city of Mecca was done, thus the Messenger of Allah has done business activities long before he partnered with Khadija and this is what led to The very typical way of business activities undertaken by the Prophet at that time he is very famous for honesty and trust in holding the promise. So that no one who interacts with him except to get extraordinary satisfaction. And this is a nuance with its own charm for the citizens of the Arabian peninsula, let alone the glory of morality as if spreading the beautiful charm of his personality too, when he did not have the money to do business himself it turns out he received a lot of capital from the rich people of Mecca who could not run their own funds and welcomes an honest person to run a business with the money they have on the basis of cooperation. And most need to be underlined the Prophet Saw business transaction is not at all to foster personal wealth but rather to build the honor and glory of business with high ethics and the results obtained just to be distributed to as many people. So that success can bring much positive impact that is success and prosperity for other people. And this is what causes the personality of the Prophet was so monumental both in earning a living and in spending fortune obtained.

For a Muslim, running a business is an act of worship so that it must begin with a sacred intention (There is no God but Allah) the right way, and the purpose and utilization of the results correctly. Because of that he got the guarantee of success from God. A Muslim entrepreneur always realizes that his status or his profession as a mandate. Therefore, its existence in any task and position is always used to achieve the mandate's salvation. Muslim entrepreneurs are constantly trying to actualize themselves, serving consumers who look forward to it or work. Everything is done with full awareness that, what is done as devotion to Allah SWT. For Muslim entrepreneurs, it is necessary to have a free-spirited soul. For him the grace of God and his provision is so infinite that the way and the effort to achieve it are very broad. This feeling makes it seem rather unattached to the existing system. But his freedom is always based on guidelines or philosophy and values that he considered correct.

The Messenger of Allah taught us to start working since the morning. After dawn prayers, if not forced, you should not sleep again. Move to find sustenance from your Rob. The angels will come down and divide the sustenance from dawn to sunset. Science and skills, two pillars for business implementation. Therefore, manage effort based on knowledge and skills on the foundation of faith and devotion is one key to the success of an entrepreneur.

Hijrah is one of the strategies of the Prophet Muhammad, which is exemplary and very suitable to be applied in the business world. The meaning of this hijrah not only means physical removal alone, but also means to abandon the actions that are forbidden by God and to do everything in his power to obey His commands. Hijrah (in the physical and spiritual sense) in business will bring new spirit, even new opportunities that are not expected before. Courage is often not innate. Because, everyone can develop courage, and if done in a truly courage it will grow and efficient. Bill Gates is a good example of this.

Starting a business with own capital though small, especially if the capital is obtained from the results of his own sweat (not from inheritance let alone begging), is a good start to success. Every human being is blessed with advantages and disadvantages. Excess or potential in a person can be developed or manage to seek fortune. Enterprises that pioneered from the hobby or potential / skills that exist in him will be more likely to succeed. Because he will always be excited, his work is fun, so he will 
love him. Almost all successful entrepreneurs start their business from a loved one and the potential that is in them. Honesty is one of the key words in the success of an entrepreneur. For an enterprise will not be able to develop itself without any connection with others. While the success and sustainability of relationships with others or other parties, is determined by the honesty of both sides. An entrepreneur should often do a relationship with business partners and even with their customers. This should be part of the integrity of a Muslim entrepreneur. Because in perfect Islam, friendship besides increasing the bond of brotherhood will also open new business opportunities.

According to the Islamic perspective a person's success in his business is not absolutely the result of his work, but rather the collective work of the number of human beings associated with it. Therefore, Islam emphasizes the importance of commitment of empowerment. So important, so according to Islam, in one's possessions there are always the rights of the poor (QS 51 / Al Dzariyat: 19). Commitment to empowerment has broad meaning, and its implementation is part of the social responsibility of the entrepreneur. The fulfillment of zakat, infaq and sadaqah should be the culture of Muslim entrepreneurs. According to Islam is clear, the treasures used to pay ZIS, will not disappear, and even our savings that will be doubled by God, in the world and in the hereafter. The relationship between business and family is like two sides of a coin so that each other cannot be separated. As an entrepreneur, in addition to be a leader in his company he also became a leader in his household. Familiarize families, wives, children, to perform fasting or circumcision prayers. As an entrepreneur, caring for orphans is a liability. Caring or nurturing in the sense of giving love and livelihood (meals, clothing, shelter and educational expenses). Better yet if we also provide supplies (science / religion / skills) so that they will be able to independently lead life in the future.

Enabling the poor is a very noble work in the sight of God and is our savings for the afterlife. If we save for the afterlife, then the world can automatically be achieved. So, in other words, if we want to be celebrated by God then we must want and dare to help other peoples. Or, by allowing poor people. Tolerance is an important attitude possessed by entrepreneurs. Thus, it appears that businesspeople are sociable, sociable, flexible, good at looking at situations and conditions, firmly holding principles but not rigid in dealing with others (including with customers). Mistakes and failures for Muslim entrepreneurs are valuable and biased to be teachers in the future. From there he will always make corrections and introspection, without being publicly known. Recognition of error or failure is part of a change of attitude (repentance). While revealing another people's disgrace remains a disgraceful act.

\section{Conclusion}

1. Building Entrepreneurship lately is no longer a necessary thing to do, but it is a must or must for every Muslim, especially Muslims in Indonesia. The obligation is caused by the urgent need for all Indonesian citizens to get out of the nation's economic weakness that causes decline in various sectors of the nation's economy so that the economy becomes stagnant which if left will worsen the state of the country.

2. A Muslim entrepreneur has a firm belief in the truth of his religion as a way of salvation, and that with his religion he will be superior. This belief makes him do business and work as a praise God and rebuild and grateful post-business.

3. Entrepreneurship and trade in the view of Islam are aspects of life that are grouped into human relations in social interactions according to the source of life problems. The problem is closely related to relationships that are horizontal, the relationship between humans who will be accounted later in the hereafter. Man is commanded to prosper the earth and bring it to a better direction and commanded to seek fortune.

4. Muslim entrepreneurs constantly strive to actualize themselves, serve consumers who put their hope in or work. Everything is done with full awareness that, what is done as devotion to Allah SWT. For Muslim entrepreneurs, it is necessary to have a free-spirited soul. For him the grace of God and his provision is so unlimited that the way and effort to achieve it is very wide. 
5. Honesty is one of the key words in the success of an entrepreneur. For an enterprise will not be able to develop itself without any connection with others. While the success and sustainability of relationships with others or other parties, is determined by the honesty of both sides.

\section{References}

Sri Wigati, M.E.I, Islamic Entrepreneurship (Application and Theory), Book of Islamic Economics Law (Muamalah) Faculty of Shariah and Law of UIN Sunan Ampel Surabaya

Sufri Eka Bhakti, MA, Journal, Entrepreneur from Perfekta Islam, Alumnus University Saints Malaysia and Lecturer of Communication and Islamic Broadcasting Faculty of Ushuluddin, Adab and Da'wah-IAIN Lhokseumawae

Ita Nurcholifah, Journal, Building Entrepreneurship: From Consensual Approach to Syariah Approach, Faculty of Sharia and Islamic Economics IAIN Pontianak.

Mohammad Darwis, Journal, Entrepreneurship In Islamic Perspective; Affirming the Paradigm of Religious Affiliation with Economy, Syarifuddin Lumajang Islamic Institute, Indonesia, Journal of Iqtishoduna p-ISSN: 2252-5661, e-ISSN: 2443-0056 |

https://www.bps.go.id/pressrelease/2018/01/02/1413/percentage-population-poor-september-2017to reach 10-12-persen.html

http://muslimpreneurs.net/fenomena-pertumbuhan-entrepreneur-di-indonesia/ http://pesantrenkhairunnas.net/2015/12/13/entrepreneurship-dalam-islam/ 